University of Nebraska - Lincoln

DigitalCommons@University of Nebraska - Lincoln

USDA National Wildlife Research Center - Staff Publications
U.S. Department of Agriculture: Animal and Plant Health Inspection Service

2015

\title{
Tick-borne Diseases in Syntopic Populations of Fallow Deer (Dama dama) and Axis Deer (Axis axis) in Northern Mexico
}

\author{
Zeferino García-Vázquez \\ CENID-PAVET, Instituto Nacional de Investigaciones Forestales, Mexico \\ J. Alfonso Ortega-S. \\ Texas A\&M University \\ Antonio Cantu-Covarruvias \\ INIFAP, Sitio Experimental Aldama, Mexico \\ Juan Mosqueda \\ Universidad Autónoma de Querétaro, Mexico \\ David G. Hewitt \\ Texas A\&M University, david.hewitt@tamuk.edu
}

See next page for additional authors

Follow this and additional works at: https://digitalcommons.unl.edu/icwdm_usdanwrc

Part of the Life Sciences Commons

García-Vázquez, Zeferino; Ortega-S., J. Alfonso; Cantu-Covarruvias, Antonio; Mosqueda, Juan; Hewitt, David G.; DeYoung, Randall W.; Campbell, Tyler A.; and Bryant, Fred C., "Tick-borne Diseases in Syntopic Populations of Fallow Deer (Dama dama) and Axis Deer (Axis axis) in Northern Mexico" (2015). USDA National Wildlife Research Center - Staff Publications. 1693.

https://digitalcommons.unl.edu/icwdm_usdanwrc/1693

This Article is brought to you for free and open access by the U.S. Department of Agriculture: Animal and Plant Health Inspection Service at DigitalCommons@University of Nebraska - Lincoln. It has been accepted for inclusion in USDA National Wildlife Research Center - Staff Publications by an authorized administrator of DigitalCommons@University of Nebraska - Lincoln. 


\section{Authors}

Zeferino García-Vázquez, J. Alfonso Ortega-S., Antonio Cantu-Covarruvias, Juan Mosqueda, David G. Hewitt, Randall W. DeYoung, Tyler A. Campbell, and Fred C. Bryant 


\title{
Tick-borne Diseases in Syntopic Populations of Fallow Deer (Dama dama) and Axis Deer (Axis axis) in Northern Mexico
}

\begin{abstract}
Zeferino García-Vázquez, ${ }^{1}$ J. Alfonso Ortega-S., ${ }^{2,6}$ Antonio Cantu-Covarruvias, ${ }^{3}$ Juan Mosqueda, ${ }^{4}$ David G. Hewitt, ${ }^{2}$ Randall W. DeYoung, ${ }^{2}$ Tyler A. Campbell, ${ }^{5}$ and Fred C. Bryant ${ }^{2}{ }^{1}$ Centro Nacional de Investigación Disciplinaria en Parasitología Veterinaria (CENID-PAVET), Instituto Nacional de Investigaciones Forestales, Agrícolas y Pecuarias, Carr. Fed. Cuernavaca-Cuautla, № 8534 Col. Progreso, Jiutepec, Morelos, C.P. 62550, México; ${ }^{2}$ Caesar Kleberg Wildlife Research Institute, Texas A\&M University-Kingsville, MSC 218, 700 University Blvd., Kingsville, Texas 78363, USA; ${ }^{3}$ INIFAP, Sitio Experimental Aldama, Aldama, Tamaulipas C.P. 89670, México; ${ }^{4}$ Facultad de Ciencias Naturales, Universidad Autónoma de Querétaro, Campus Juriquilla, C.P. 76230, México; ${ }^{5}$ US Department of Agriculture Animal and Plant Health Inspection Service, Wildlife Services, National Wildlife Research Center Florida Field Station, 2820 E University Ave., Gainesville, Florida 32641, USA; ${ }^{6}$ Corresponding author (email: poncho.ortega@tamuk.edu)
\end{abstract}

ABSTRACT: We harvested 21 fallow deer (Dama dama) and 17 axis deer (Axis axis) in northern Mexico. Two fallow deer were positive for Babesia bigemina and one for Babesia bovis. Amplicons had the expected 170 and 291 base pairs and were identical to $B$. bigemina (S45366) and B. bovis (M38218), respectively.

Populations of exotic ungulates have been established outside their native range in many parts of the world (Chapman and Chapman 1975; Feldhammer et al. 1988), including Mexico, even though current regulations ban the transport and release of exotic ungulates in Mexico. These introductions have potential detrimental effects on health of livestock and native wildlife and on resource availability for native species. Additionally, exotic species may be more resistant to some diseases, conferring a competitive advantage over native species (Davidson and Crow 1983; Davidson et al. 1985; Flynn et al. 1990).

Babesia bovis and Babesia bigemina are transmitted by cattle fever ticks (Rhipicephalus spp.) and cause bovine babesiosis. Fever ticks are one-host ticks that preferentially feed on cattle (Bos primigenius) but also feed on other ungulates, such as whitetailed deer (Odocoileus virginianus; Pound et al. 2010). The role of exotic ungulates in cattle fever tick host-vector-pathogen dynamics is poorly known.

Cattle ranches in northern Mexico increasingly use recreational ventures to generate income. Consequently, native populations of white-tailed deer and exotic species such as fallow deer (Dama dama) and axis deer (Axis axis) are increasing and may serve as hosts for ticks that are vectors for Babesia spp. Molecular and serologic evidence show Babesia spp. in white-tailed deer from northern Mexico and southern Texas (Cantu et al. 2009; Ramos et al. 2010), and Cardenas-Canales et al. (2011) reported B. bovis and B. bigemina in nilgai (Boselaphus tragocamelus) in northern Mexico. Thus, exotic ungulates may harbor Babesia spp. Serologic monitoring of domestic livestock and wildlife on ranches will help determine the prevalence, incidence, and possible patterns of spread of Babesia and other tickborne pathogens.

Axis and fallow deer were introduced into central and northern Mexico for hunting. Axis deer occur in at least 50 extensive operations, with a total area of 160,100 ha; fallow deer exist in 44 operations on 116,000 ha (Álvarez-Romero and Medellín 2005). No information exists on the epidemiology of Babesia in cervids in Mexico. We used serology to determine whether axis and fallow deer had been exposed to $B$. bovis and $B$. bigemina and nested PCR to detect Babesia DNA on a ranch in northern Mexico.

This study was conducted on a 400-ha, high-fenced, private ranch in Soto la Mari- 
na, Tamaulipas, Mexico, $\left(23^{\circ} 34^{\prime} 108^{\prime \prime} \mathrm{N}\right.$, $\left.97^{\circ} 53^{\prime} \mathrm{W}\right)$. Ungulate species living on the ranch are axis and fallow deer, sika (Cervus nippon), blackbuck (Antilope cervicapra), Barbary sheep (Ammotragus lervia), native white-tailed deer, and domestic cattle. Cattle have been allowed to graze pastures periodically since 2007 as a tick control strategy. Exotic wildlife and cattle use the same source of water at a water control structure.

Twenty-one fallow deer and 17 axis deer of different sexes and ages were captured using drop nets. Nets were set and baited with corn $3 \mathrm{~d}$ before the capture. Blood samples were collected from the jugular vein in ethylenediaminetetraacetic acidK3 anticoagulant and centrifuged to obtain serum at the laboratory of the Instituto de Investigaciones Forestales, Agrícola y Pecuarias-Aldama, Tamaulipas, and stored at $4 \mathrm{C}$.

Blood samples were analyzed by nested PCR following Figueroa et al. (1993) using specific primers for $B$. bovis that identified the gene Rap-1 and B. bigemina. Amplified PCR products were electrophoresed on agarose gels, stained with ethidium bromide, visualized, and photographed under ultraviolet light. Amplicons from two $B$. bigemina-positive and one B. bovis-positive blood samples were sequenced.

Indirect immunofluorescence antibody (IFA) test was used to test for evidence of exposure to $B$. bovis and $B$. bigemina. Babesia bovis and B. bigemina-infected bovine erythrocytes were obtained from in vitro culture as described by Levy and Ristic (1980) and Vega et al. (1985) and were smeared and kept at $-70 \mathrm{C}$ until used. The IFA slides were fixed with acetone and incubated with each of the serum samples at a screening dilution of 1:100 for $30 \mathrm{~min}$ at $37 \mathrm{C}$. This dilution was chosen because there is no cross-reactivity between $B$. bovis and B. bigemina in cattle. The reaction was detected with protein $\mathrm{G}$ conjugated with Alexa 488 (Molecular Probes, Eugene, Oregon, USA) at 1:100 followed by incubation for
$30 \mathrm{~min}$ at $37 \mathrm{C}$. As positive controls, bovine sera from cattle experimentally infected with $B$. bovis or $B$. bigemina were used at the same dilution. Sera from uninfected deer were used as negative controls. Finally, a Giemsa-stained blood smear from each blood sample was examined under oil immersion at $1,000 \times$ to detect hemoparasites.

We found two positive samples for $B$ bigemina based on amplicon size (170 base pairs [bp]), and one positive sample for $B$. bovis (291 bp) in fallow deer. Amplicons from positive samples had the expected length and were identical to published sequences of both species $(B$. bovis accession M38218; B. bigemina accession S45366). No positive samples were found from axis deer.

Four samples were antibody-positive for $B$. bovis, two from axis deer and two from fallow deer, whereas 19 samples were $B$. bigemina antibody-positive, five axis and 13 fallow deer. Only one fallow deer sample was positive for antibodies to both $B$. bigemina and $B$. bovis. No Babesia parasites definitively identifiable by piriform shape in joined pairs were observed by microscopic examination of the Giemsa-stained blood films.

Evidence of Babesia spp. in fallow deer has not been reported previously. Bovine babesiosis is widespread in Tamaulipas and has been reported in white-tailed deer (Cantu et al. 2009) and nilgai (CardenasCanales et al. 2011). The presence of other non-cattle hosts such as fallow deer complicates the epidemiology of bovine babesiosis. Subclinical infection may occur in white-tailed deer, providing a reservoir of infection (Gallatin et al. 2003). According to Holman et al. (2000), subclinical infections with Babesia odocoilei were not found in fallow and axis deer; rather, white-tailed deer resident within the ranch appeared to be the reservoir of infection.

The presence of antibodies and DNA of $B$. bovis and B. bigemina raises the still unanswered question of whether fallow 
deer and axis deer are susceptible to subclinical disease.

We acknowledge the US Department of Agriculture Animal and Plant Health Inspection Service, the Caesar Kleberg Wildlife Research Institute, Juan Romero, and M.V.Z. Hector Hugo Jaramillo for the provided funding and the Centro Nacional de Parasitología Veterinaria (CENID-PAVET) from Instituto Nacional de Investigaciones Forestales, Agrícolas, y Pecuarias (INIFAP) for their contribution to the laboratory analyses. Our study was performed under a scientific collection permit issued by the State of Tamaulipas, Comisión Estatal para la Conservación y el Aprovechamiento de la Vida Silvestre. This is Caesar Kleberg Wildlife Research Institute publication 14-110.

\section{LITERATURE CITED}

Álvarez-Romero J, Medellín RA. 2005. Axis axis. Vertebrados superiores exóticos en México: Diversidad, distribución y efectos potenciales. Bases de datos SNIB-CONABIO. Proyecto UO2O. Instituto de Ecología, Universidad Nacional Autónoma de México, México, D.F., México, 7 pp.

Cantu A, Ortega-S JA, Mosqueda J, Garcia-Vasquez Z, Henke SE, George JE. 2009. Epizotiology of Babesia bovis and Babesia bigemina in freeranging white-tailed deer in northeastern Mexico. J Parasitol 95:536-542.

Cardenas-Canales EM, Ortega-Santos JA, Campbell TA, Garcia-Vasquez Z, Cantu-Covarrubias A, Figueroa-Millan JV, Deyoung RW, Hewitt DG, Bryant FC. 2011. Nilgai antelope in northern Mexico as a possible carrier for cattle fever ticks and Babesia bovis and Babesia bigemina. J Wildl Dis 47:777-779.

Chapman D, Chapman N. 1975. Fallow deer: Their history, distribution and biology. Terence Dalton Limited, Lavenham, UK, 271 pp.

Davidson WR, Crow CB. 1983. Parasites, diseases, and health status of sympatric populations of sika deer and white-tailed deer in Maryland and Virginia. J Wildl Dis 19:345-348.

Davidson WR, Crum JM, Blue JL, Sharp DW, Phillips JH. 1985. Parasites, diseases, and health status of sympatric populations of fallow deer and white-tailed deer in Kentucky. $J$ Wildl Dis 21:153-159.

Feldhammer GA, Farris-Renner KC, Barker CM. 1988. Dama dama. Mamm Species 317:1-8.

Figueroa JV, Chieves LP, Johnson GS, Buening GM. 1993. Multiplex polymerase chain reaction based assay for the detection of Babesia bigemina, Babesia bovis and Anaplasma marginale DNA in bovine blood. Vet Parasitol 50:69-81.

Flynn LB, Shea SM, Lewis JC, Marchinton RL. 1990. Part III: Population statistics, health, and habitat use. In: Ecology of sambar deer on St. Vincent National Wildlife Refuge, Florida. Bulletin 25. Tall Timbers Research Station, Tallahassee, Florida, pp. 63-96.

Gallatin LL, Irizarry-Rovira AR, Renninger ML, Holman PJ, Wagner GG, Sojka JE, Christian JA. 2003. Babesia odocoilei infection in elk. J Am Vet Med Assoc 223:1027-1032.

Holman PJ, Madeley J, Craig TM, Allsopp BA, Allsopp MT, Petrini KR, Waghela SD, Wagner GG. 2000. Antigenic, phenotypic and molecular characterization confirms Babesia odocoilei isolated from three cervids. J Wildl Dis 36:518-530.

Levy MG, Ristic M. 1980. Babesia bovis: Continuous cultivation in a microaerophilous stationary phase culture. Science 207:1218-1220.

Pound JM, George JE, Kammlah DM, Lohmeyer LH, Davey RB. 2010. Evidence for role of white-tailed deer (Artiodactyla: Cervidae) in epizootiology of cattle ticks and southern cattle ticks (Acari: Ixodidae) in reinfestations along the Texas/Mexico border in South Texas: A review and update. J Econ Entomol 103:211-218.

Ramos CM, Cooper SM, Holman PJ. 2010. Molecular and serologic evidence for Babesia bovislike parasites in white-tailed deer (Odocoileus virginianus) in south Texas. Vet Parasitol 172: 214-220.

Vega CA, Buening GM, Green TJ, Carson CA. 1985. In vitro cultivation of Babesia bigemina. Am J Vet Res 46:416-420.

Submitted for publication 28 July 2014.

Accepted 8 August 2014. 